\title{
Field performance of perennial ryegrass (Lolium perenne) infected with toxin- free fungal endophytes (Neotyphodium spp.)
}

\author{
A.J. POPAY ${ }^{1 \dagger}$, D.E. HUME ${ }^{2}$, J.G. BALTUS ${ }^{1}$, G.C.M. LATCH ${ }^{2}$, B.A. TAPPER ${ }^{2}$, T.B. LYONS ${ }^{2}$, \\ B.M. COOPER ${ }^{3}$, C.G. PENNELL ${ }^{4}$, J.P.J. EERENS ${ }^{1}$ and S.L. MARSHALL ${ }^{1}$ \\ ${ }^{1}$ AgResearch, Ruakura Research Centre, Private Bag 3123, Hamilton \\ ${ }^{2}$ AgResearch, Grasslands Research Centre, Private Bag 11008, Palmerston North \\ ${ }^{3}$ AgResearch, Kerikeri Research Centre, P.O. Box 23, Kerikeri \\ ${ }^{4}$ AgResearch, Canterbury Agriculture and Science Centre, P.O. Box 60, Lincoln \\ †popaya@agresearch.cri.nz
}

\begin{abstract}
A national series of six small plot trials were sown in 1996 and four in 1997 to evaluate the performance of six novel fungal endophytes in Grasslands Nui perennial ryegrass. These endophytes do not produce the mammalian toxins, ergovaline and lolitrem $\mathrm{B}$, but produce peramine, a feeding deterrent to the major ryegrass pest, Argentine stem weevil (ASW). Trials included the naturally occurring endophyte (wild-type) which produces both toxins, and an endophyte-free (nil) treatment. Pasture production was measured regularly and samples were taken at least once each summer-autumn from all trials for assessment of ASW damage. Black beetle larval damage was recorded on three trials. The toxin-free endophytes, AR1, AR12, AR22 and the wild-type were equally effective at reducing ASW adult feeding and larval damage significantly below that which occurred in nil treatments. Ryegrass infected with AR1, AR12, AR22 and the wild-type endophyte was damaged less by black beetle larvae than ryegrass without endophyte. The effect of AR24 on insect damage was variable and two other toxin-free endophytes, AR17 and AR506, which had low infection rates, seldom reduced either ASW or black beetle damage. Yield differences between treatments were found on two of 21 sampling occasions between October and December and 12 of 30 sampling occasions between January and April. During summer-autumn, wild-type, AR1, AR12 and AR22 gave higher ryegrass yields than the nil, AR17 and AR506 treatments. In the second year of the 1996-sown trials, productivity of ryegrass with AR1 in the summer-autumn tended to be lower than that of the wild-type with significant differences occasionally occurring. Yield differences were correlated with either ASW or black beetle damage in North Island trials and with percent endophyte infection at all sites. Differences in yield at Lincoln, Canterbury, were attributed to pasture mealy bug.
\end{abstract}

Three conclusions were drawn from these results:

1. Endophytes are very important for maximising ryegrass yield during summer and early autumn.

2. The effect of endophytes on yield is at least partly due to the insect resistance they impart.

3 . The field performance of three toxin-free endophytes, AR1, AR12 and AR22, equalled that of the wild-type in terms of increased insect resistance but did not always match it in plant growth.

Keywords: AR1, Argentine stem weevil, black beetle, endophyte strain, ergovaline, insect damage, lolitrem B, Neotyphodium lolii, ryegrass yield

\section{Introduction}

The presence of the fungal endophyte, Neotyphodium lolii, greatly enhances persistence and productivity of perennial ryegrass in New Zealand pastures. The advantages gained from the presence of endophyte have been attributed to the resistance it confers on its host plant to the major ryegrass pest Argentine stem weevil (ASW) (Listronotus bonariensis). Adult ASW feed on the leaf blades of grass and lay their eggs in the pseudostems. Larvae hatch and burrow into the tillers where their feeding ultimately kills the tiller. The damage that ASW causes annually to improved pastures in New Zealand has been estimated to be as high as $\$ 202$ million (Prestidge et al. 1991). Fungal endophytes also provide resistance to their ryegrass hosts against other insect pests in New Zealand. Adult black beetle (Heteronychus arator) are deterred by endophyte infection of ryegrass (Ball \& Prestidge 1992) which results in few eggs being laid in pastures with high endophyte levels and hence low populations of the root-feeding larvae. Black beetle causes substantial damage to northern North Island pastures. Populations of a little recognised pest in Canterbury, pasture mealy bug (Balanococcus poae) have also been found recently to be reduced by endophyte-infected perennial ryegrass (Pennell \& Ball unpublished data). 
Aside from resistance to pests, fungal endophytes may confer other growth advantages on their host grasses. Tall fescue infected with the endophyte, Neotyphodium coenophialum, has been shown in the USA to have greater tiller production and herbage mass (De Battista et al. 1990) and to be more tolerant of drought (Bacon 1993) than its uninfected counterpart. Growth advantages and abiotic stress tolerance in endophyte-infected ryegrass have been less clearly documented. In a controlled environment study which provided ideal growing conditions, Latch et al. (1985) found that endophyte-infected plants yielded $38 \%$ more total dry matter than uninfected clonal plants. Other studies, however, have failed to show any differences in growth between endophyte-infected and uninfected ryegrass (Hume 1993). In Australia, endophyte-infected ryegrass tends to persist better than uninfected plants in areas where rainfall is marginal for growth (Cunningham et al. 1993) but drought tolerance in infected ryegrass has not been clearly demonstrated in experimental work (Barker et al. 1997; Eerens et al. 1998; Hume et al. 1993).

In order to fully exploit the natural pest resistance provided by fungal endophyte infection, it is necessary to eliminate, or at least significantly reduce, the effects of the mammalian toxins that the fungus produces. All known strains of endophyte in New Zealand produce three major alkaloids, ergovaline, lolitrem B and peramine (Christensen et al. 1993). All three have some role in protecting ryegrass from attack by ASW (Popay \& Rowan 1994) but peramine is considered to be the most important because it is a powerful feeding deterrent to the adult weevil (Rowan et al. 1990). By finding endophytes which do not produce the mammalian toxins, ergovaline and lolitrem $\mathrm{B}$, but continue to produce peramine, it is possible to eliminate the adverse effects of endophyte on grazing animals (Fletcher \& Easton 1997) without compromising resistance to ASW. An endophyte, AR1, which has these properties, has been shown in screenhouse trials to reduce ASW damage to the same degree as the natural endophytes which produce all three alkaloids (Popay \& Ball 1998).

In New Zealand, a wide range of environments impact on the performance of ryegrass in pasture through climate, soil type and regional differences in pest populations. In addition, different endophyte strains can have differing effects on plant growth which are apparently unrelated to metabolite production (Easton 1990). An evaluation of the field performance of ryegrass infected with selected toxin-free endophytes was therefore undertaken in several regions of New Zealand, which are representative of a range of climatic variables, soil types and insect pests. Assessments made on these trials were aimed at determining whether ryegrass infected with selected endophytes remained toxin-free, had a high degree of resistance to insect pests and had growth and productivity characteristics which would not place it at a selective disadvantage in New Zealand pasture systems.

\section{Methods}

Perennial ryegrass, cv. Grasslands Nui, infected with different endophytes was established in precultivated seed beds at six sites in New Zealand in March 1996 and four sites in March 1997 (Table 1). In this paper, data are only presented for those sites and seasons where we have adequate insect damage information. All selected endophytes in these trials, except AR17, produce peramine and all produce little or no lolitrem B or ergovaline. These endophytes were all inoculated into the same seed line. Each trial also included Nui without endophyte (the same seed line as that with the toxinfree endophytes) and a different seed line of Nui infected with the wild-type endophyte, which produces all three alkaloids. All trials sown in 1996 used the same line of seed, as did trials sown the following year.

Table 1 Trial sites and treatments (AR, Wild-type = endophyte strains; Nil = endophyte absent).

\begin{tabular}{|c|c|c|}
\hline & 1996-Sown trials & 1997-Sown trials \\
\hline Sites & $\begin{array}{l}\text { Kerikeri, Northland } \\
\text { Tokanui, Waikato } \\
\text { Te Puke, Bay of Plenty } \\
\text { Aorangi, Manawatu } \\
\text { Lincoln North, Canterbury } \\
\text { Lincoln Central, Canterbury }\end{array}$ & $\begin{array}{l}\text { Kerikeri, Northland } \\
\text { Ruakura, Hamilton } \\
\text { Aorangi, Manawatu } \\
\text { Lincoln Central, } \\
\text { Canterbury }{ }^{\dagger}\end{array}$ \\
\hline Treatments & $\begin{array}{l}\text { AR1, AR12』, AR17, AR24, } \\
\text { AR506, wild-type, nil }\end{array}$ & $\begin{array}{l}\text { AR1, AR12, AR17, } \\
\text { AR22, AR24, } \\
\text { wild-type, nil }\end{array}$ \\
\hline $\begin{array}{l}\text { I AR12 no } \\
\dagger \quad \text { Data fron }\end{array}$ & $\begin{array}{l}\text { luded in trials at Tokanui and } \\
s \text { trial not presented in this } p\end{array}$ & $\begin{array}{l}\text { Te Puke } \\
\text { aper }\end{array}$ \\
\hline
\end{tabular}

Treatments were arranged in a randomised block design usually in plots of $15 \mathrm{~m}^{2}$, with four replicates of each treatment. For some treatments at some sites, seed availability was limited and so number of replicates and plot size were reduced.

At all sites, nitrogen fertiliser was applied after each grazing or mowing at rates estimated at $3 \%$ of the mean overall production. Herbicides were applied as necessary to control grass and broadleaf weeds.

Chemistry: In January or February of each year, analyses were conducted on 80-100 tillers cut individually from each plot and then bulked for analysis. Harvested material was stored at $-20^{\circ} \mathrm{C}$, then freeze-dried and 
milled before analysis by HPLC for the alkaloids peramine, lolitrem B and ergovaline.

ASW damage: Between October 1996 and March 1997, samples were taken from each trial twice in the spring and three times in the summer for assessment of ASW damage. This sampling regime continued in the 1997/ 98 and 1998/99 seasons for the Tokanui and Ruakura trials and in 1997/98 for the Te Puke trial. For all other trials, sampling was carried out once during the summer. On each sampling occasion, a tiller was cut at ground level from 20-25 randomly selected plants in each plot. The leaf blades of each tiller were scored for adult ASW feeding on a scale of $0-5$ where $0=$ no feeding and $5=$ extensive feeding over the entire leaf area. Each tiller was then dissected and examined for ASW eggs and larval damage.

Black beetle damage: In February 1997, the number of plants killed by black beetle was estimated visually for each plot in the 1996 Kerikeri trial. The 1997 Kerikeri trial was assessed for black beetle larval damage in February 1998 by examining 10 randomly selected plants in each plot. Plants that pulled away from the ground easily and had a larva or larval frass beneath them were recorded as damaged. A similar assessment was carried out on all plants in four $30 \mathrm{~cm}^{2}$ quadrats per plot in the Ruakura trial in February 1999.

Endophyte: The proportion of ryegrass tillers infected with endophyte was estimated for each plot in all trials in November of each year. Twenty tillers chosen at random were removed from each plot and checked for the presence of endophyte. In November 1996 this was done by microscopic examination of leaf sheath tissue stained in aniline blue. In 1997 and 1998, an immunoblot technique was used to assess endophyte presence.
Yields: Pasture yields were measured above a height of $3 \mathrm{~cm}$ at 4-6-weekly intervals depending on plant growth. This was done by cutting a mower strip at Kerikeri and representative quadrats at Te Puke, Ruakura and Aorangi. At Lincoln, pasture mass was determined using a calibrated rising plate meter. In addition to dry matter determination, pasture composition was regularly assessed by herbage dissection of samples taken from random or quadrat cuts. The proportion of ryegrass in the herbage dissection samples was used to estimate the ryegrass yield data presented here. After yield measurements had been taken, all plots were mob stocked with sheep for 24-48 hours, except at Kerikeri where plots were mown. After grazing, plots were topped to a common height if necessary.

Data analysis: An analysis of variance using least mean squares was conducted on yield measurements taken between October and April, ASW adult feeding and larval damage, and on black beetle damage in 1997 at Kerikeri and at Ruakura in 1999. Black beetle damage at Kerikeri in 1998 was analysed by chi-square. Linear regression analyses were carried out to investigate relationships between endophyte levels, insect damage and yield.

\section{Results}

Chemistry: All novel endophyte treatments have substantially lower levels of ergovaline and lolitrem B than the wild-type plots (Figures 1A, B). AR12 and AR22 appear to have slightly higher levels of toxins than the nil treatment but this is within the margins of error for these analyses. These results may also suggest that these plots have a low level of contamination with wild-type endophyte.

Figure 1 Mean concentrations of the alkaloids ergovaline and lolitrem $B$ in samples of ryegrass infected with different strains of endophyte taken from the Aorangi 1996 Trial in March 1998 (A) and from the Ruakura 1997 Trial in January 1998 (B). Wild = wild-type; AR = new strains of endophyte; Nil = endophyte-free.

(A) Aorangi 1996 Trial

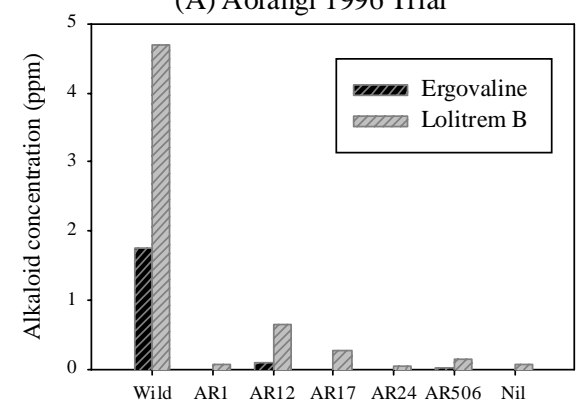

(B) Ruakura 1997 Trial

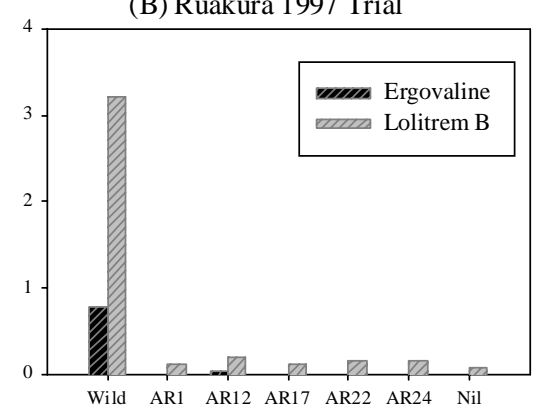


Insect damage: Adult ASW feeding scores on ryegrass differed significantly between treatments on 13 of 17 sampling occasions conducted on all sites between January and March, 1997-1999. Treatments with lower $(\mathrm{P}<0.05)$ adult feeding than the nil treatment were the toxin-free endophytes, AR1, AR12, AR22, and AR24, and the wild-type endophyte (Table 2). Adult feeding on AR17 and AR506 was almost always similar to the feeding on ryegrass without endophyte.

The number of tillers damaged by ASW larvae varied considerably between sites and years, but largely reflected the effects of the different treatments on adult feeding scores (Table 2, Figures 2A, C). The treatments with the least amount of ASW larval damage were AR1, AR12, AR22 and the wild-type, with no significant differences between these four treatments. AR24, which significantly reduced adult feeding, was not always as effective as these latter endophytes at reducing larval damage. The treatments with the highest levels of ASW larval damage were nil, AR17 and AR506. Lincoln was the only trial site where larval damage levels were low on all sampling occasions.

Visible damage from black beetle larvae occurred in the 1996 and 1997 sowings at Kerikeri in 1997 and 1998 respectively, and in the Ruakura trial in 1999. Results for all three trials (Table 2, Figure 2E) consistently showed that less plant damage occurred in the wild-type, AR1, AR12 and AR22 treatments compared with nil and AR17 treatments. For the Kerikeri 1998 and Ruakura 1999 samples, the differences between these groups of treatments were significant $(\mathrm{P}<0.05)$.

Endophyte: Examples of the endophyte infection rate for different treatments in the 1996 and 1997 trials are shown in Figures 3A \& $\mathrm{C}$ respectively. Because all trails were sown with the same seed in each year, these examples are representative of other sites. Frequency of infection was low for AR17 (1996 and 1997 trials) and AR506 (sown 1996 only) and for the 1997 sowings of wild-type and AR24. For trials sown in 1996, invasion by volunteer ryegrass increased endophyte infection levels in the nil treatments to 54\% at Te Puke and 27\% at Tokanui by November 1998, whereas at Kerikeri, Aorangi and Lincoln the nil plots remained almost free of endophyte. Nil treatments in the 1997 trial at Kerikeri also increased markedly in endophyte content reaching $27 \%$ in the November 1998 sampling.

Yields: The mean ryegrass content for each trial, given as a percentage of green herbage, was: 1996-sown trials - Kerikeri $80 \%$, Te Puke 82\%, Tokanui 78\%, Aorangi 98\%, Lincoln (both trials) 100\%; 1997-sown trials Kerikeri $75 \%$, Ruakura $86 \%$, Aorangi $98 \%$, Lincoln $100 \%$. Of 21 yield measurements taken from the trials in the months of October, November and December, significant differences between treatments were recorded only twice (data not presented). In the 1996 sowing at Aorangi there was a significant difference between the highest yielding treatment (AR12) and all others in

Table 2 Argentine stem weevil adult feeding score and larval damage, and black beetle larval damage recorded on different sampling occasions in January $(\mathrm{J})$ or February $(\mathrm{F})$ at various sites.

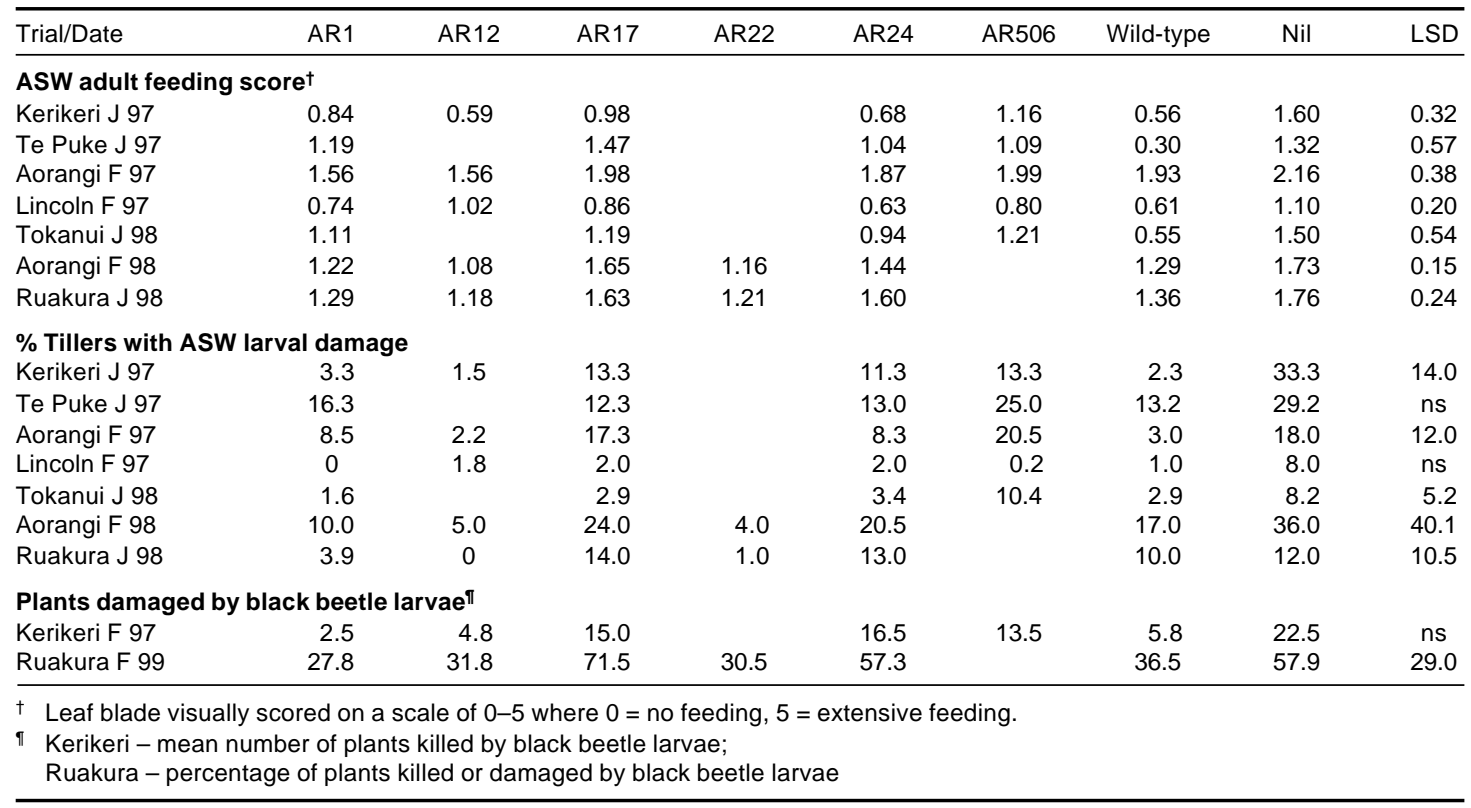


Figure 2 Effect of different endophyte treatments on Argentine stem weevil (ASW) larval damage at Tokanui (A) and Aorangi (C) in February 1997 and on black beetle larval damage at Kerikeri in February 1998

(E) with associated ryegrass yields at each site (B, D, F). Error bars represent the SEM.
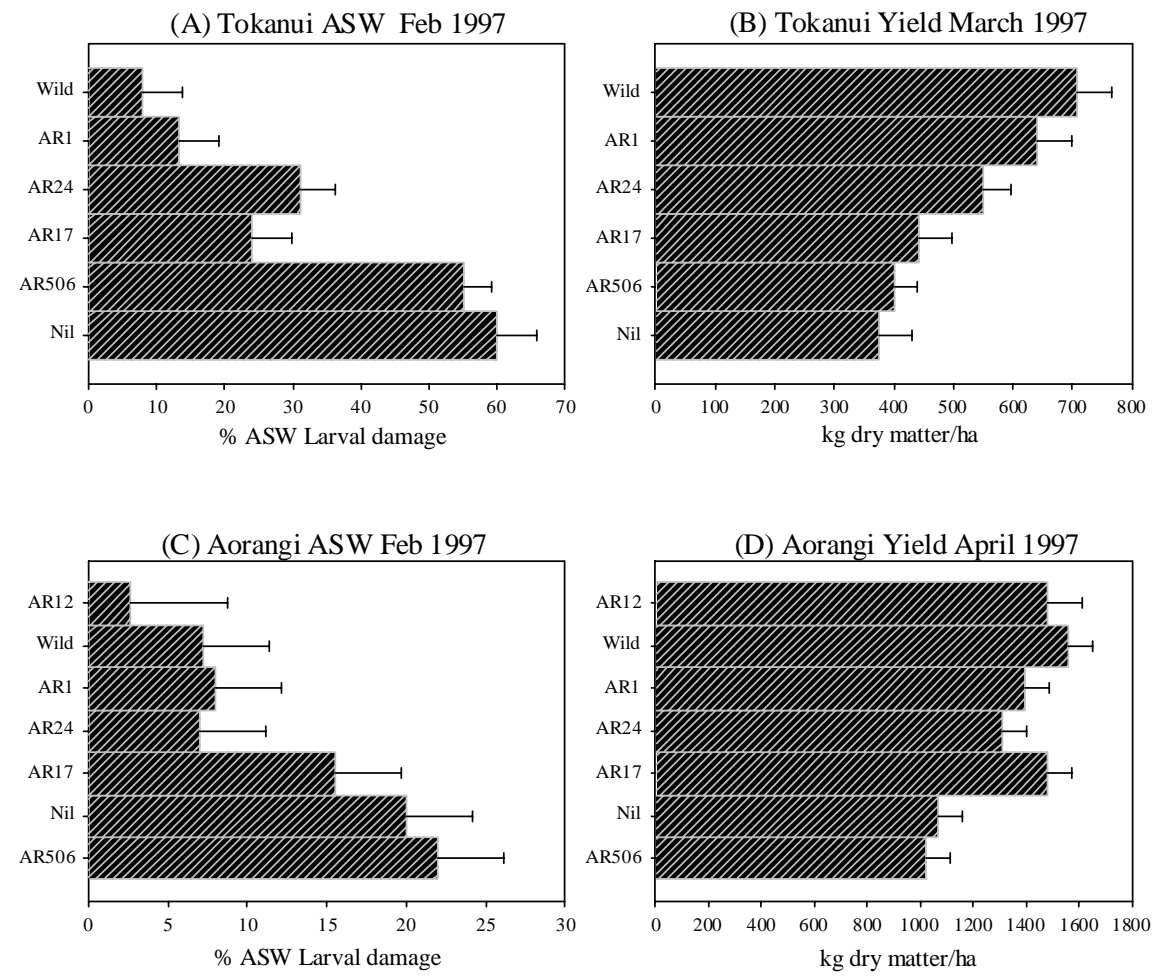

(E) Kerikeri Black Beetle Feb 1998

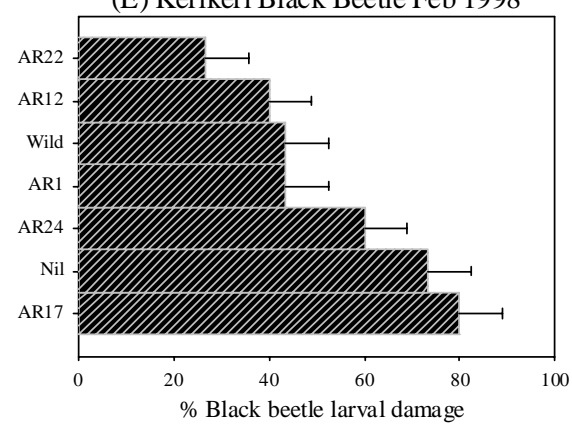

December 1997. In October 1996 in the Lincoln Central trial, however, nil, AR24 and AR506 outyielded both AR1 and AR12.

In contrast to the spring and early summer, yield measurements taken between January and April were much more likely to show significant differences between treatments. Thirty sampling occasions on all trials were analysed for this period and on 12 of these, significant differences $(\mathrm{P}<0.05)$ between treatments were found with one occurring on at least one occasion

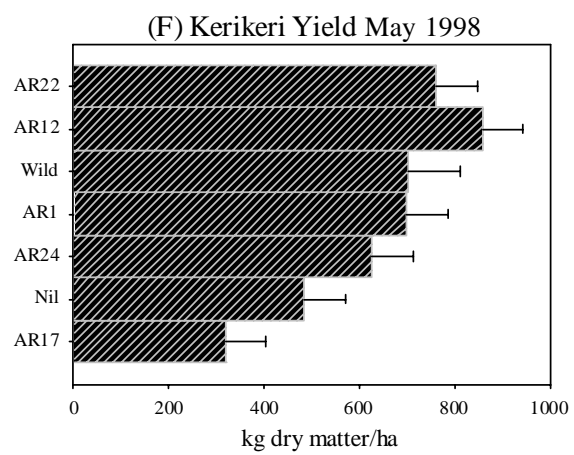

at each site (Table 3). The highest yielding treatments were the wild-type, AR12, AR1 and AR22 and the lowest yielding treatments, nil, AR506 and AR17 (Figures 2B, D, F; 3B, D). Yields from AR24 treatments were variable. In the first year of the 1996 sown trials, the productivity of AR1 and AR12 equalled that of the wild-type. In the second year, however, productivity of AR1 declined during the summer-autumn and on two occasions was significantly lower than the wild-type (Te Puke in March 1998 and Lincoln Central, February 
Figure 3 The proportion of tillers infected with endophyte in different treatments in a 1996-sown trial at Lincoln (A) and a 1997-sown trial at Ruakura (C) determined in November 1997, with associated ryegrass yields measured in March 1998 at Lincoln (B) and in January 1998 at Ruakura (D). Error bars represent the SEM.

(A) Lincoln Central \% Endophyte Nov. 1997

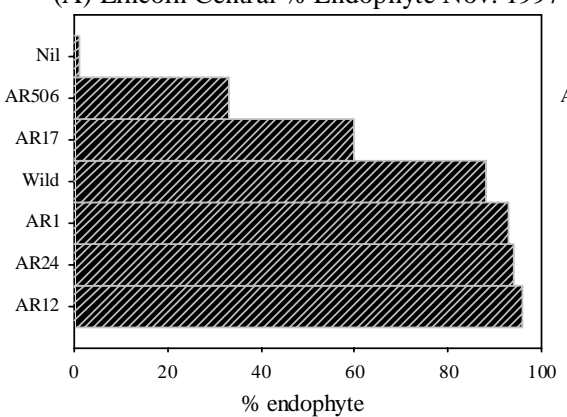

(C) Ruakura \% Endophyte Nov 1997

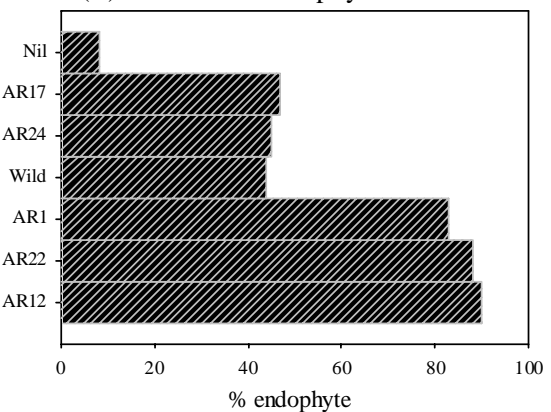

1998). In the 1997-sown trials, in which the wild-type plots were less than $60 \%$ infected with endophyte, no differences in yield between this treatment and AR1 were recorded.

Growth rate of endophyte-free ryegrass between January and April 1997 at Tokanui was 53\% of that in the wild-type plots and $58 \%$ of that in AR1. In April 1997 at Aorangi, the nil endophyte treatment yielded $32 \%$ less than the wild-type and $24 \%$ less than AR 1. During the 1998 summer/autumn period in the 1997 sown trials at Ruakura (January), Kerikeri (March) and Aorangi (February), AR12 outyielded nil treatments by $48 \%, 77 \%$ and $56 \%$ respectively, AR1 outyielded nil by $38 \%, 44 \%$ and $46 \%$, and yields of AR22 were $40 \%$, $57 \%$ and $44 \%$ higher than nil. By comparison, the wild-type, which had low endophyte infection levels, outyielded nil at the same sites by $21 \%, 48 \%$ and $18 \%$.

In the first summer-autumn period for the 1996sown trials, total production from AR1 varied from $13 \%$ less to $11 \%$ more than production from wild-type at different sites. In the second summer-autumn period, yield of AR1 relative to the wild-type declined at all
(B) Lincoln Central Yield March 1998

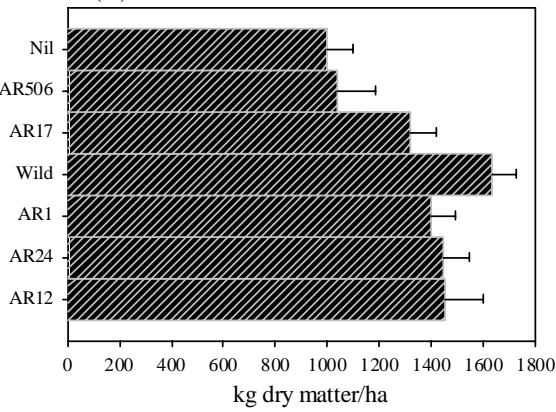

(D) Ruakura Yield Jan 1998

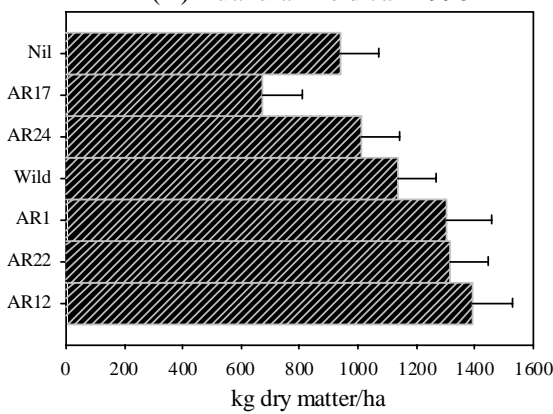

sites, ranging from $37 \%$ less at Te Puke to $7 \%$ less in the Lincoln North trial.

Endophyte/insect/yield interactions: On most sampling occasions there was a significant negative correlation between ASW adult feeding score and percent endophyte content of the plots determined in the November preceding ASW sampling (data not presented). Similarly, the percentage of tillers with larval damage was also negatively correlated with percent endophyte infection.

Linear regression analysis was used to determine if insect damage and/or percent endophyte infection had a significant influence on yield within the growth period that insect damage mainly occurred. With the exception of the Lincoln Central trial in February 1998, yield was significantly correlated with insect damage or endophyte levels, or both, on each occasion where treatment had significantly affected ryegrass productivity (Table 3 ). Thus the highest yielding treatments (i.e., wild-type, AR1, AR12 and AR22) were those with the least insect damage (typical examples are given in Figures $2 \mathrm{~A} \& \mathrm{~B}$, 
Table 3 Linear correlations $\left(R^{2}\right)$ between yield $(\mathrm{kg} \mathrm{DM} / \mathrm{ha})$ and insect damage and yield and endophyte content of plots. Correlations were negative between yield and insect damage and positive between yield and percent endophyte.

\begin{tabular}{|c|c|c|c|c|c|c|c|}
\hline \multirow[b]{3}{*}{ Site } & \multirow{3}{*}{$\begin{array}{l}\text { Yield Response } \\
\text { Date }\end{array}$} & \multirow{2}{*}{\multicolumn{4}{|c|}{ - Predictors }} & \multirow{2}{*}{\multicolumn{2}{|c|}{--- \% Endophyte ${ }^{\dagger}$}} \\
\hline & & & & & & & \\
\hline & & Type $\mathbb{1}$ & Date & $\mathrm{R}^{2}$ & $\mathrm{P}$ & $\mathrm{R}^{2}$ & $\mathrm{P}$ \\
\hline \multirow{3}{*}{$\begin{array}{l}\text { Tokanui } \\
\text { Aorangi } 1996\end{array}$} & Mar 97 & ASW & Feb 97 & 46 & $<0.001$ & 60 & $<0.001$ \\
\hline & Jan 97 & ASW & Jan 97 & - & ns & 27 & 0.004 \\
\hline & April 97 & ASW & Feb + Mar 97 & 42 & 0.001 & 39 & $<0.001$ \\
\hline \multirow{3}{*}{$\begin{array}{l}\text { Te Puke } \\
\text { Lincoln Central }\end{array}$} & Mar 98 & ASW & Jan 98 & 18 & 0.045 & 26 & 0.018 \\
\hline & Feb 98 & ASW & Feb 98 & - & ns & - & ns \\
\hline & Mar 98 & ASW & Feb 98 & - & ns & 56 & $<0.001$ \\
\hline \multirow[t]{2}{*}{ Lincoln North } & Feb 98 & ASW & Feb 98 & - & ns & 37 & 0.001 \\
\hline & April 98 & ASW & Feb 98 & - & ns & 24 & 0.009 \\
\hline \multirow[t]{2}{*}{ Ruakura } & Jan 98 & ASW & Jan 98 & 18 & 0.016 & 29 & 0.002 \\
\hline & Mar 99 & BB & Feb 99 & 33 & 0.001 & - & ns \\
\hline Aorangi 1997 & Feb 98 & ASW & Feb 98 & 14 & 0.032 & 21 & 0.010 \\
\hline Kerikeri 1997 & Mar 98 & BB & Feb 98 & 53 & $<0.001$ & - & ns \\
\hline \multicolumn{8}{|c|}{$\begin{array}{l}\text { ASW = Percentage of tillers damaged by Argentine stem weevil larvae } \\
\mathrm{BB}=\text { Percentage of plants killed or damaged by black beetle larvae }\end{array}$} \\
\hline
\end{tabular}

C \& D, E \& F) and/or the highest endophyte infection rates (typical examples in Figures 3A \& B, C \& D). When yield was correlated with ASW larval damage, it was also correlated with percent endophyte infection. Conversely yield was not correlated with percent endophyte infection when it was correlated with black beetle larval damage (Kerikeri 1997 Trial, 1998 season; Ruakura 1999 season). There were also occasions when yield was significantly related to endophyte content of plots but not related to the occurrence of either ASW or black beetle (Lincoln Central and Lincoln North, 1998 season).

\section{Discussion}

Depression of summer and early autumn pasture production is a common occurrence in New Zealand and has a large impact on animal production. Undoubtedly moisture stress is the main cause of reduced plant growth in this period but often pasture pests are a major contributory factor. The damage caused by these pests is insidious and, coming as it does when soil moistures are at their lowest, often goes unrecognised. It is during this time that the protection of ryegrass against insect attack afforded by fungal endophytes is most important. This has been demonstrated in the results from the trial series described in this paper where, on several occasions during the summer-autumn period, the wild-type endophyte and some of the toxin-free endophytes have outyielded ryegrass without endophyte or with low rates of infection (e.g., AR17 and AR506). Yield differences between treatments were correlated with insect damage on seven of the 12 occasions when ryegrass productivity differed between treatments. On four of the remaining five occasions when treatment affected ryegrass productivity, yield was correlated with endophyte content of plots. All these occurred in the two Lincoln trials in 1998. A severe infestation of pasture mealy bug was noted in these trials at this time and found to be reduced by the presence of endophyte (Pennell \& Ball unpublished data). Since ASW damage levels were very low, it seems likely that the pasture mealy bug was responsible for these yield differences.

The negative correlations between yield and insect damage, although statistically significant, were not always strong, with low correlation coefficients indicating that other factors may also be influencing yield. Variability in yield measurements and mis-timing of insect damage sampling have probably contributed to reducing correlation. It is likely, also, that the amount of insect damage in plots is underestimated when it is measured on only one or two occasions during each season whereas its effects on ryegrass tend to be cumulative. An interaction between soil moisture levels and insect damage, whereby the effects of insect damage on plant growth are exacerbated by dry conditions, adds to the variation in ryegrass yield. These results do not rule out the possibility, however, that other endophyterelated factors are contributing to differences in plant growth.

In New Zealand pastures, which are naturally infected with wild-type endophyte, the population dynamics of ASW and the amount of damage caused by this pest are closely linked with availability of endophytefree tillers (Barker et al. 1989; Barker \& Addison 1993). Similarly, in the trials reported here, the relationship between percent endophyte infection and ASW adult feeding and larval damage indicates that the endophyte content of the plots in these trials has been a major 
factor governing ASW behaviour. Differences in damage between treatments can therefore be attributed mainly to variation in infection levels rather than to the effectiveness of the different strains. Thus the ability of ryegrass swards, which are highly infected with the toxin-free strains AR1, AR12, AR22 and AR24, to resist ASW is similar to the wild-type endophyte. This provides further evidence that the ASW feeding deterrent, peramine, which is produced by all strains of endophyte used in these trials, except AR17, is important for maintaining a high degree of resistance to ASW. In contrast to this, black beetle damage was not well correlated with percent endophyte infection of the sward. Similarly, where black beetle larval damage significantly influenced yield, the latter was also not correlated with percent endophyte, unlike the situation with ASW larval damage. This strongly suggests that resistance to black beetle varies with endophyte strain. In particular, AR24 and AR17 appear to have suffered a high degree of damage, which is disproportionate to their infection levels, when compared with AR1, AR12, AR22 and the wild-type. Reduced levels of larval damage to endophyteinfected ryegrass are mediated through the effects of the endophyte on adult feeding as larval black beetle appear not to be sensitive to the presence of endophyte (Popay \& Ball 1998). Ergovaline and other ergopeptine alkaloids, produced by the wild-type strain but not by the toxin-free endophytes, are the only fungal metabolites that have been shown so far to affect black beetle adult feeding (Ball et al. 1997). The lower damage levels to ryegrass infected with AR1, AR12 and AR22 strains confirm other studies (Ball et al. 1994; Popay and Ball 1998; Ball unpublished) indicating that other factors are present in certain endophyte-infected grasses which render them resistant to black beetle adults. Variation in the production of these unknown factors may thus account for the differences in black beetle larval damage between strains. In small plot studies such as these, however, some random damage may occur through movement of larvae and of adults during oviposition. Although the absence of ergovaline does not appear to reduce protection from black beetle adults in mature ryegrass, it may do so at the seedling stage. Recent evidence has shown that seedling AR1 (less than 2 months old) is more susceptible to black beetle adult feeding than seedlings containing the wild-type, but also less susceptible than endophyte-free seedlings (Popay unpublished data). The implications this may have for subsequent infestation of AR1 pastures with black beetle larvae have yet to be determined.

Where insect damage has occurred, the presence of endophytes strongly influenced plant performance with yields in endophyte-infected treatments up to $77 \%$ higher than nil treatments in a single growth period. The importance of endophyte infection to yield was further reinforced in the 1997-sown trials in which wild-type plots had less than $60 \%$ infection rates. The wild-type did not yield significantly higher than endophyte-free ryegrass in these trials, in contrast to the 1996 trials when it frequently out-yielded this treatment. The advantages to pasture production provided by the presence of wild-type endophyte have been shown previously. In a trial comparing pastures with low and high endophyte infection levels, Barker and Addison (1993) recorded a $28 \%$ yield increase for endophyteinfected ryegrass over a 10-month period between July and May. Other studies have used insecticide to obtain yield increases of $17 \%$ over the summer-autumn period through control of ASW (Barker et al. 1984) and Prestidge et al. (1984) obtained an annual increase in ryegrass yield of $6-17 \%$ with the greatest yield increases recorded over the summer-autumn period.

Although insect resistance and endophyte infection are factors influencing yield, it is apparent in these trials that endophyte strain is also important. Direct comparisons show that the productivity of AR1 was lower than that of the wild-type in the second season of the 1996-sown trials despite these two treatments having similar levels of insect damage. The reasons for the decline in the performance of AR1 are unknown and further research is being done to elucidate them. However, data for the 1999 summer-autumn period, which have not been presented in this paper, generally show that the performance of AR1 relative to the wildtype has improved on the previous season. This suggests that growth of ryegrass infected with different endophyte strains varies with season.

In this series of national trials, the performance of the novel endophytes AR1, AR12 and AR22, has matched that of the wild-type in terms of insect resistance, but not always in plant growth. Swards containing these endophytes have negligible levels of the mammalian toxins, ergovaline and lolitrem B, compared with wild-type swards. However a low level of toxins in AR12 and AR22 plots requires further investigation to confirm that this is due to contamination with the wild-type endophyte, before we can be totally satisfied that these strains are toxin-free. AR1 is the only one of these endophytes which has been evaluated in grazing trials and it has been found to have no adverse effects on sheep (Fletcher \& Easton 1997; Fletcher 1999). AR24 shows a reasonable degree of resistance to ASW but is susceptible to black beetle and yields of ryegrass infected with this endophyte have seldom differed from nil treatments. Neither AR17 nor AR506 have high transmission rates of viable fungi which has resulted in low infection rates in plots. Both these endophytes have shown only low levels of insect 
resistance and this has been reflected, on several occasions, in poor yields.

\section{ACKNOWLEDGEMENTS}

Neil Cox and David Baird for data analyses. Liz Davies, Wayne Simpson, Vanessa Burton, Mohi Marsh and Kathryn Pankhurst for technical assistance. This research was funded by the Foundation for Research, Science and Technology.

\section{REFERENCES}

Bacon, C.W. 1993. Abiotic stress tolerances (moisture, nutrients) and photosynthesis in endophyte-infected tall fescue. Agriculture, Ecosystems and Environment 44: 123-142.

Ball, O.J.-P.; Prestidge, R.A. 1992. The effect of the endophytic fungus Acremonium lolii on adult black beetle (Heteronychus arator) feeding. pp. 201-204. In: Proceedings of the $45^{\text {th }}$ New Zealand Plant Protection Conference.

Ball, O.J.-P.; Christensen, M.J.; Prestidge, R.A. 1994. Effect of selected isolates of Acremonium endophytes on adult black beetle (Heteronychus arator) feeding. pp. 227-231. In: Proceedings of the $47^{\text {th }}$ New Zealand Plant Protection Conference.

Ball, O.J.-P.; Miles, C.O.; Prestidge, R.A. 1997. Ergopeptine alkaloids and Neotyphodium loliimediated resistance in perennial ryegrass against adult Heteronychus arator (Coleoptera: Scarabaeidae). Journal of Economic Entomology 90: 1382-1391.

Barker, D.J.; Hume, D.E.; Quigley, P.E. 1997. Negligible physiological responses to water deficit in endophyte-infected and uninfected perennial ryegrass. pp. 137-140. In: Neotyphodium/Grass Interactions. Eds. Bacon, C.W.; Hill, N.S. Plenum Press, New York \& London.

Barker, G.M.; Addison, P.J. 1993. Argentine stem weevil populations and damage in ryegrass swards of contrasting Acremonium infection. pp. 161-168. In: Proceedings $6^{\text {th }}$ Australasian Conference on Grassland Invertebrate Ecology.

Barker, G.M.; Pottinger, R.P.; Addison, P.J. 1989. Population dynamics of the Argentine stem weevil (Listronotus bonariensis) in pastures of Waikato, New Zealand. Agriculture, Ecosystems and Environment 26: 79-115.

Christensen, M.J.; Leuchtmann, A.; Rowan, D.D.; Tapper, B.A. 1993. Taxonomy of Acremonium endophytes of tall fescue (Festuca arundinacea), meadow fescue ( $F$. pratensis), and perennial ryegrass (Lolium perenne). Mycological Research 97: 1083-1092.
Cunningham, P.J.; Foot, J.Z.; Reed, K.F.M. 1993. Perennial ryegrass (Lolium perenne) endophyte (Acremonium lolii) relationships: the Australian experience. Agriculture, Ecosystems and Environment 44: 157-168.

De Battista, J.P.; Bouton, J.H.; Bacon, C.W.; Siegel, M.R. 1990. Rhizome and herbage production of endophyte-removed tall fescue clones and populations. Agronomy Journal 82: 651-654.

Easton, H.S. 1990. Endophyte strain and growth of perennial ryegrass. pp. 131-133. In: Proceedings of an International Symposium on Acremonium/Grass Interactions.

Fletcher, L.R. 1999. 'Non-toxic' endophytes in ryegrass and their effect on livestock health and production. Ryegrass endophyte: an essential New Zealand symbiosis. Grassland Research and Practice Series No. 7: 133-139.

Fletcher, L.R.; Easton, H.S. 1997. The evaluation and use of endophytes for pasture improvement. pp. 209227. In: Neotyphodium/Grass Interactions. Eds. Bacon, C.W.; Hill, N.S. Plenum Press, New York \& London.

Eerens, J.P.J.; Lucas, R.J.; Easton, H.S.; White, J.G.H. 1998. Influence of endophyte (Neotyphodium lolii) on morphology, physiology, and alkaloid synthesis of perennial ryegrass during high temperature and water stress. New Zealand Journal of Agricultural Research 41: 219-226.

Hume, D.E. 1993. Agronomic performance of New Zealand pastures: Implications of Acremonium presence. pp. 31-38. In: Proceedings of the Second International Symposium on Acremonium/Grass Interactions: Plenary Papers.

Hume, D.E., Popay, A.J.; Barker, D.J. 1993. Effect of Acremonium endophyte on growth of ryegrass and tall fescue under varying levels of soil moisture and Argentine stem weevil attack. pp. 161-164. In: Proceedings of the Second International Symposium on Acremonium/Grass Interactions.

Latch, G.C.M.; Hunt, W.F.; Musgrave, D.R. 1985. Endophytic fungi affect growth of perennial ryegrass. New Zealand Journal of Agricultural Research 28: 165-168.

Popay, A.J.; Rowan, D.D. 1994. Endophytic fungi as mediators of plant-insect interactions. pp 83-104. In: Insect-Plant Interactions, Vol. V. Ed. Bernays E.A. CRC Press, USA.

Popay, A.J.; Ball O.J.-P. 1998. The development of fungal endophytes as a pest management tool for New Zealand grasslands. pp. 374-371. In: Proceedings $6^{\text {th }}$ Australasian Applied Entomological Research Conference (Vol.1).

Prestidge, R.A.; Van der Zijpp, S.; Badan, D. 1984. Effects of Argentine stem weevil on pastures in the 
Central Volcanic Plateau. New Zealand Journal of Experimental Agriculture 12: 323-331.

Prestidge, R.A.; Barker, G.M.; Pottinger, R.P. 1991.

The economic cost of Argentine stem weevil in pastures in New Zealand. pp. 165-170. In: Proceedings of the $44^{\text {th }}$ New Zealand Weed and Pest Control Conference.

Rowan, D.D.; Dymock, J.J.; Brimble, M.A. 1990. Effect of fungal metabolite peramine and analogs on feeding and development of Argentine stem weevil (Listronotus bonariensis). Journal of Chemical Ecology 16: 1683-1695. 